\title{
TANPA INCUMBENT, KETERLIBATAN POLITIK APARATUR BIROKRASI PADA PEMILUKADA SERENTAK MENURUN (Studi Perbandingan Pemilukada Langsung Kabupaten Pandeglang Tahun 2010 dengan Tahun 2015)
}

\author{
Ombi Romli \\ e-mail: ombi_cls@yahoo.co.id
}

\begin{abstract}
ABSTRAK
Kabupaten Pandeglang adalah salah satu daerah di Provinsi Banten yang sudah melaksanakan Pemilukada langsung sejak tahun 2005. Pemilukada langsung di Kabupaten Pandeglang selalu menunjukan adanya keterlibatan politik aparatur birokrasi dalam bentuk dukung mendukung terhadap calon Bupati/Wakil Bupati. Tujuan penelitian ini untuk membandingkan keterlibatan politik aparat ur birokrasi pada Pemilukada di Kabupaten Pandeglang pada tahun 2010 yang diikuti oleh incumbent, dengan Pemilukada Serentak Tahun 2015 yang tidak diikuti oleh incumbent. Penelitian ini menggunakan metode deskriptif dengan pendekatan kualitatif. Pengumpulan data melalui observasi, wawancara, dan studi pustaka.

Berdasarkan hasil penelitian, Pilkada langsung yang dilaksanakan tahun 2010 di Kabupaten Pandeglang yang diikuti oleh incumbent menunjukan keterlibatan politik aparatur birokrasi dalam bentuk dukung mendukung terhadap calon Bupati/ Wakil Bupati, tampak jelas terbuka dengan intensitas yang tinggi. Sedangkan pada Pemilukada serentak tahun 2015 di Pandeglang yang tanpa diikuti incumbent keterlibatan politik aparatur birokrasi dalam bentuk dukung-mendukung terhadap calon Bupati/Wakil Bupati tampak tertutup dengan intensitas rendah. Dengan demikian keterlibatan politik aparatur birokrasi dalam bentuk dukung mendukung calon Bupati dan Wakil Bupati Kabupaten Pandeglang pada Pemilukada serentak Tahun 2015 mengalami penurunan, jika dibandingkan dengan Pemilukada langsung tahun 2010. Penurunan ini terjadi salah satu faktor utamanya karena Pemilukada langsung serentak tahun 2015 di Kabupaten Pandeglang tidak diikuti oleh incumbent.
\end{abstract}

Kata Kunci: Incumbent, Ketrlibatan politik aparatur birokrasi, pemilukada langsung serentak

132 | CosmoGov, Vol. 2 No. 1, April 2016 


\begin{abstract}
Pandeglang is a distric in Banten province which has already run local direct election since 2005. Any time the local direct election is run, the involvement of bureaucratic appartus to support certain candidate for regent and vice Regent. The purpose of the study is to compare the involvement of bureaucratic apparatus at the direct election in Pandeglang in 2010 which was followed by the incumbent, with the recent concurrent local election in 2015 which was not followed by the incumbent. The research uses qualitative approach by which the collection of date is gathered through observation, interviews, and literature studies.

The findings show that during 2010 direct election by which the incumbent was in power, the involvement of bureaucratic officials to support the candidate was massively identified and and very intensive. Meanwhile, during the 2015 election of which no incumbent was in contest, the involvement of government officials was still carried out silently as well as with low intensity. The findings suggest that the involvement of government officials to support certain candidates experienced a significant decrease during the last concurrent local election in comparison with the 2010 election. The main factor of this decrease is the absence of incumbent in 2015 election.
\end{abstract}

Keywords: Incumbent, apparatus involvement, concurrent election

\section{PENDAHULUAN}

Sejak diberlakukannya UndangUndang Nomor 32 Tahun 2004 yang sekarang sudah diganti dengan Undang-Undang No 23 Tahun 2014 Tentang Pemerintahan Daerah, tatanan pemerintahan di Indonesia telah mengalami banyak perubahan. Perubahan yang cukup signifikan adalah dengan dilaksankannya Pemilihan Kepala Daerah (Pilkada) secara langsung yang maksudnya untuk mengembalikan kedaulatan ke tangan rakyat.

Selain itu Pilkada langsung merupakan sarana yang diyakini dapat menghasilkan pemimpin daerah yang terbaik karena dipilih secara lebih demokratis, sehingga mampu meningkatkan kesejahtraan dan membawa kemajuan bagi daerah.

Akan tetapi Pilkada langsung yang sudah dilaksankan sejak tahun 2005 ternyata menimbulkan berbagai persoalan dalam proses penyelenggaraannya. Salah satunya adalah terlibatnya aparatur birokrasi pemerintah daerah dalam Pilkada/Pemilukada langsung.

Pada kenyataanya di lapangan Pemilukada langsung di Indonesia diwarnai oleh berbagai pelanggaran salah satunya oleh aparatur birokrasi yang terlibat dalam dukung mendukung terhadap calon Bupati/ 
Wakil Bupati terutama jika Pilkada/ Pemilukada langsung tersebut diikuti oleh incumbent.

Data dari Pusat Penelitian dan Pengkajian Kepaniteraan dan Sekretariat Jenderal Mahkamah Konstitusi tahun 2011 menunjukan bahnwa dalam sengketa Pilkada langsung yang menjadi bahan gugatan adalah banyak terjadinya kecurangan secara terstuktur sistematis dan masif yang melibatkatkan aparatur birokrasi untuk mendukung calon Bupati/Wakil Bupati seperti yang terjadi di Kabupaten Konawe Selatan, Kabupaten Gersik, Kota Tanjungbalai, dan Kabupaten Sumbawa. ${ }^{113}$

Padahal dalam aturan perudangundangan dengan jelas dinyatakan bahwa aparatur birokrasi itu tidak boleh memihak kepada salah satu kontestan Pemilukada langsung.

"Pasangan Calon dilarang melibatkan pegawai negeri sipil, anggota Tentara Nasional Indonesia, dan anggota Kepolisisan Negara Republik Indonesia sebagai peserta kampanye dan juru kampanye dalam pemilihan kepala daerah dan wakil kepala daerah". ${ }^{114}$
Alasan mengapa aparatur birokrasi harus netral dalam Pemilukada karena pada masa lalu di era orde baru, aparatur birokrasi berpihak menjadi salah satu pendukung/ anggota kekuatan politik Golongan Karya (Golkar) yang menimbulkan ketidakadilan dalam politik.

Keberpihakan aparatur birokrasi kepada salah satu kontestan politik dalam Pilkada langsung di era reformasi sudah barang tentu sama menimbulkan ketidakadilan politik yang merugikan kontestan politik yang lain, yang pada akhirnya merusak sendi-sendi kehidupan demokrasi yang sedang dibangun.

Selain itu dampak dari aparatur birokrasi terlibat dalam politik praktis dengan mendukung salah satu peserta Pemilukada berpengaruh terhadap keberlangsungan pembangunan daerah. Karena biasanya aparatur birokrasi yang diberikan imbalan berupa jabatan sebagai balas jasa politik cenderung kurang profesional dalam menjalankan tugas dan fungsinya. Mereka akan lebih menjadi alat untuk "melayani" kepentingan politik ekonomi penguasa ketimbang melayani masyarakat. Sehingga

113. M. Makrus Ali, 2011, Tafsir Kostitusional Pelanggaran Pemilukada yang bersifat Sistematis, Terstruktur, dan Masif, Pusat Penelitian dan Pengkajian Kepaniteraan dan Sekretarian Jenderal Mahkamah Konstitusi, hal 8-10

114. Undang-Undang No 32 Tahun 2004 Tentang Pemerintahan Daerah Pasal 79

134 Cosmogov, Vol. 2 No. 1, April 2016 
dampaknya pembangunan daerah menjadi terabaikan.

Kabupaten Pandeglang adalah salah satu daerah tertinggal di Provinsi Banten yang sudah melaksanakan Pemilukada langsung sebanyak tiga kali yaitu tahun 2005, 2010, dan 2015. Pilkada langsung tahun 2005 dan 2010 dimenangkan oleh incumbent. Tahun 2005 dimenangkan oleh Dimyati Natakusumah yang sebelumnya menjabat Bupati Kabupaten Pandeglang, dan Tahun 2010 dimenangkan oleh Erwan Kurtubi yang sebelumnya sebagai Wakil Bupati/Pejabat Bupati.

Pada tahun 2015 ini Kabupaten Pandeglang adalah salah satu daerah yang melaksankan Pemilihan Kepala Daerah langsung serentak di Indonesia. Dalam Pemilukada langsung serentak tahun 2015 ini ada perbedaan jika dibandingkan Pilkada langsung sebelumnya tahun 2010, yaitu dalam Pemilukada Serentak langsung kali ini tidak diikuti oleh incumbent.

Bupati Kabupaten Pandeglang Erwan Kurtubi dan Wakil Bupati Pandeglang Heiyani tidak lagi menjadi kontestan dalam Pemilukada langsung serentak Kabupaten Pandeglang yang di dilaksankan tanggal 9 Desember 2015.

115. Radar Banten, Edisi 10 Desember 2015
Dari hasil Pemilihan Kepala Daerah langsung serentak di Provinsi Banten menunjukan fakta yang menarik di empat daerah kabupaten/ kota yaitu : Kabupaten Serang, Kota Cilegon, Kota Tangerang Selatan, dan Kabupaten Pandeglang. Calon yang memenangkan Pilkada langsung serentak 9 Desember 2015 itu semuanya adalah incumbent, kecuali Kabupaten Pandeglang. ${ }^{115}$

Tatu Chasanah adalah pemenang di Kabupaten Serang merupakan Wakil Bupati Kabupaten Serang, Iman Ariyadi pemenang di Kota Cilegon merupakan Wakil Walikota Cilegon, dan Airin Rachmi Diany adalah Wali Kota Tangerang Selatan. Sementara itu di Kabupaten Pandeglang pemenangnya Irna Narulita yang bukan Bupati atau Wakil Bupati Kabupaten Pandeglang. Irna Narulita adalah anggota DPR dari Partai Persatuan Pembangunan (PPP) yang bukan merupakan incumbent.

Keadaan ini semakin menguatkan asumsi bahwa peserta Pemilukada langsung yang berstatus sebagai incumbent akan selalu memenangi Pemilukada langsung. Mengapa bisa terjadi demikian?, karena selain diuntungkan tingkat popularitas yang lebih dikenal oleh masyarakat 
setempat, juga incumbent selalu mendapat dukungan dari aparatur birokrasi pemerintah daerah setempat.

Melihat realita diatas penulis merasa tertarik melakukan penelitian tentang keterlibatan aparat ur birokrasi dalam Pemilukada di Kabupaten Pandeglang Provinsi Banten. Tulisan ini bertujuan untuk membandingkan keterlibatan aparatur birokrasi di Kabupaten Pandeglang pada tahun 2010 yang diikuti oleh incumbent, dengan Pemilukada Serentak Tahun 2015 yang tidak diikuti oleh incumbent.

\section{TINJAUAN PUSTAKA}

Berbicara tentang birokrasi tidak akan lepas dari pengaruh Max Weber yang dikenal sebagai tokoh yang melahirkan konsep tipe birokrasi ideal. Menurut Weber birokrasi merupakan ciri dari pola organisasi yang strukturnya dibuat sedemikian rupa sehingga secara maksimal dapat memanfaatkan tenaga ahli. Organisasi harus diatur secara rasional, impersonal, dan bebas dari sikap prasangka. Dengan demikian sebagai suatu sistem otorita yang ditetapkan secara rasional dalam berbagai perat uran untuk meng- organisasi secara teratur, bersifat spesialisasi, hirarkis, dan terelaborasi. ${ }^{116}$

Kemudian Max Weber sebagaikama dikutif Martin Albrow menjelaskan bagaimana mekanisme, peran, dan kedudukan pekerja (staf) di dalam organisasi legal rasional sebagai berikut:

1. Para anggota staf besifat bebas secara pribadi, dalam arti hanya menjalankan tugas-tugas impersonal sesuai dengan jabatan mereka;

2. Terdapat hirarki jabatan yang jelas;

3. Fungsi-fungsi jabatan ditentukan secara tegas;

4. Para pejabat diangkat berdasarkan suatu kontrak;

5. Para pejabat dipilih berdasarkan kulaifikasi profesional, ideal didasarkan pada suatu diploma (ijazah) yang diperoleh melalui ujian;

6. Para pejabat memiliki gaji dan biasanya dilengkapi hak-hak pension. Gaji bersifat berjenjang menurut kedudukan dalam hirarki. Pejabat dapat selalu menempati posnya, dan dalam keadaan-keadaan tertentu, pejabat juga dapat diberhentikan;

7. Pos jabatan adalah lapangan kerja bagi para pejabat

116. Departemen Pendidikan dan Kebudayaan; Administrasi Pendidikan Materi Dasar Pendidikan Program Akta mengajar V, Buku II C, Jakarta 1982 
8. Suatu struktur karir dan promosi sangat dimungkinkan atas dasar senioritas dan keahlian (merit) serta menurut keunggulan (superior);

9. Pejabat sangat mungkin tidak sesuai dengan pos jabatanya maupun dengan sumber-sumber yang tersedia di dalam pos tersebut dan pejabat tunduk pada sistem disiplin kontrol yang seragam. ${ }^{117}$

Dengan demikian model ideal birokrasi yang dimaksudkan oleh Max Weber adalah suatu sistem tata kerja dan aturan dalam birokrasi yang harus dijalankan secara rasional, profesional, dan bersifat independen. Weber tidak menginginakan adanya unsur intervensi politik didalamnya.

Menurut Miftah Thoha model birokrasi Weber yang selama ini difahami merupakan sebuah mesin yang disiapkan untuk menjalankan dan mewujudkan tujuan. Dengan demikian, setiap pekerja atau pejabat dalam birokrasi pemerintah merupakan pemicu dan penggerak dari sebuah mesin yang kepentingan pribadi (each civil servant is a cog in machine with no personally interest). ${ }^{118}$
Dalam kaitan ini maka setiap pejabat tidak memiliki tanggungjawab politik, kecuali bidang-bidang tugas dan tanggung jawab yang dibebankan kepadanya. Sepanjang tugas dan tangungjawab sebagai mesin itu dijalankan sesuai dengan proses dan prosedur yang telah ditetapkan, maka akuntabilitas pejabat birokrasi pemerintah telah diwujudkan. Pemikiran seperti ini menjadikan birokrasi pemerintah bertindak sebagai kekuatan yang netral dari pengaruh kepentingan kelas atau kelompok tertentu.

Berbeda dengan Max Weber, Karl Marx seorang sosiolog yang juga berasal dari Jerman memliiki pendapatnya sendiri tentang Birokrasi. Meskipun birokrasi tidak mendapat tempat utama dalam pemikiran Karl Marx, tetapi Marx selalu mengkaitkan birokrasi dengan struktur kekuasaan yang ada dalam suatu negara. Birokrasi menurut Marx merupakan instrumen yang dipergunakan oleh kelas yang dominan (berkuasa) untuk melaksankan dominasinya atas kelas-kelas sosial lainnya. Konsep Marx ini dipahami dalam kerangka umum teorinya tentang perjuangan kelas, krisis kapitalisme, dan pengembangan komunisme. ${ }^{119}$ Dengan demikian

117. Martin Albraw, 2004, Birokrasi, Tiara Wacana, Yogyakarta

118. Miftah Thoha. 2009, Birokrasi Pemerintah Indonesia di Era Reformasi, Kencana, Jakarta, hal 119. Miftah Thoha, 2009, Birokrasi Pemerintah Indonesia di Era Reformasi, Kencana, Jakarta, Hal 22 
Marx menganggap birokrasi hanya sebagai alat/instrument politik bagi kelas yang berkuasa untuk mengeksploitasi kelas-kelas lainnya yang tujuannya untuk mempertahankan kekuasaan.

Di Indonesia Politik birokrasi memiilki akar sejarah dan perkembangannya sendiri. Sebelum kedatangan bangsa asing pada abad ke 16, birokrasi menganut sistem kekuasaan dan pengaturan masyarakat yang berbentuk kerajaan. Dalam sistem kerajaan, pucuk pimpinan ada di tangan raja dan semua masyarakat harus tunduk dan patuh pada kehendak sang raja. Termasuk para pegawai (birokrasi) pemerintahan yang terbentuk pada waktu itu adalah birokrasi kerajaan yang dipilih atau diangkat oleh raja harus tunduk dan patuh pada raja.

Menurut Sarwono sebagaimana dikutif Agus Dwiyanto menyebutkan ciri-ciri birokrasi kerajaan pada waktu itu adalah sebagai berikut :

1. Penguasa menganggap menggunakan administrasi publik sebagai urusan pribadi;

2. Administrasi adalah perluasan rumah tangga istananya;

3. Tugas pelayanan ditujukan ke- pada pribadi sang raja;

4. Gaji dari raja kepada pegawai kerajaan pada hakekatnya adalah anugerah yang juga dapat ditarik sewaktu-waktu sekehendak raja; dan

5. Para pejabat kerajaan dapat bertindak sekehendak hatinya terhadap rakyat seperti yang dilakukan oleh raja. ${ }^{120}$

Dengan demikian sesungguhnya birokrasi yang ada pada waktu itu bersifat tradisional merupakan alat kekuasaan pengusa (raja) yang memiliki tugas melayani kepentingan pribadi raja. Tugas pejabat birokrasi harus melaksankan perintah atau kebijakan-kebijakan raja sebagai penguasa.

Kemudian pada masa penjajahan kolonial Belanda berkuasa di Indonesia terjadi dualisme sistem birokrasi pemerintahan. Disatu sisi telah mulai diperkenalkan dan diberlakukan sistem administrasi kolonial (Binnenlandsche Bestuur) yang mengenalkan sistem birokrasi dan administasi modern, sedangkan pada sisi lain, sistem administrasi tradisional (Inheemshe Bestuur) masih tetap dipertahankan oleh pemerintah kolonial. ${ }^{121}$

120. Agus Dwiyanto, 2009, Reformasi Birokrasi Publik di Indonesia, Gadjah Mada University Press. Hal 10

121. Agus Dwiyanto, Ibid, hal 14

$138 \mid$ Cosmogov, Vol. 2 No. 1, April 2016 
Dengan demikian meskipun telah terjadi perubahan sistem birokrasi pada masa pemerintahan kolonial, tetapi secara substansi sebenarnya tidak mengubah corak birokrasi pemerintahan dalam hubungannya dengan publik. Pengaruh kekuasaan pemerintah masih tetap kuat dan posisi birokrasi masih menjadi instrumen politik penguasa.

Di era orde baru birokrasi merupakan mesin politik utama orde baru, dimana keterlibatan birokrasi dalam politik dilegalkan oleh aturan perundang-undangan demi mempertahankan rezim. Menurut UndangUndang No 3 Tahun 1975 Tentang Partai Politik dan Golongan Karya, Pegawai Negeri Sipil dapat menjadi anggota Partai Politik atau Golongan Karya (Golkar) dengan sepengetahuan atau izin tertulis pejabat yang berwenang. ${ }^{122}$

Dengan adanya Undang-Undang ini berarti birokrasi diperbolehkan untuk menjadi anggota kekuatan politik/partai politik yang ada pada waktuitu. Meskipun pada kenyataanya terjadi manipulasi politik dan ketidakadilan politik. Karena Pegawai
Negeri Sipil (PNS) secara keseluruhan pada akhirnya menjadi anggota Golongan Karya (Golkar) yang menjadi pilar utama kekuatan politik Orde Baru bersama dengan Angkatan Bersenjata Republik Indonesia (ABRI) yang lebih dikenal dengan istilah ABG (ABRI, Birokrasi, Golkar). Setiap Pemilihan Umum pada masa Orde Baru birokrasi tampil menjadi mesin politik yang epektif dalam memenangkan Golongan Karya (Golkar).

Menurut Bintoro Tjokroamidjodjo birokrasi pemerintah sebagai alat politik utama "partai" pemerintah yang berkuasa mengurangi orientasinya terhadap pengabdian umum dan pelayanan publik. Ia tidak lagi public servant melainkan bagian utama dari penguasa dan kekuasaan politik. $^{123}$

\section{METODE PENELITIAN}

Penelitian ini menggunakan metode deskriptif dengan pendekatan kulitatif. Menurut Moh Nazir Metode deskriptif adalah suatu metode dalam meneliti status sekelompok manusia,

122. Undang-Undang No. 3 Tahun 1975 Tentang Partai Politik dan Golongan Karya Pasal 8

123. Bintoro Tjokroamidjojo, 2001, Reformasi Administrasi Publik, Universitas Krisnadwipayana, Jakarta. ha 16 
suatu obyek, suatu set kondisi, suatu sistem pemikiran, ataupun suatu kelas peristiwa pada masa sekarang. Tujuan dari penelitian ini adalah untuk membuat deskripsi, gambaran atau lukisan secara sistematis, faktual dan akurat mengenai fakta-fakta, sifat, serta hubungan antar fenomena yang diselidiki. ${ }^{124}$

Menurut Whitney yang dikutif Moh. Nazir, metode deskriptif adalah pencarian fakta dengan interpretasi yang tepat. Penelitian deskriptif mempelajari masalah-masalah dalam masyarakat, serta tata cara yang berlaku dalam masyarakat serta situasi-situasi tertentu, termasuk tentang hubungan, kegiatan-kegiatan, sikap-sikap, pandangan-pandangan, serta proses-proses yang sedang berlangsung dan pengaruh-pengaruh dari suatu fenomena. Dalam metode deskriptif, peneliti bisa saja membandingkan fenomena-fenomena tertentu sehingga merupakan suatu studi komparatif. ${ }^{125}$

\section{Menurut Lexi Moeleong} Penelitian kualitatif adalah penelitian yang menghasilkan prosedur analisis yang tidak menggunakan prosedur analisis statatistik atau cara kuantitatif lainnya. ${ }^{126}$ Sedangkan Bogdan dan Taylor sebagaimana yang dikutif Lexy Moeleong, metode kualaitatif sebagai prosedur penelitian yang menghasilkan data deskriptif berupa kata-kata tertulis atau lisan dari orang-orang prilaku yang diamati. ${ }^{127}$

Dalam konteks penelitian ini yang dibandingkan adalah keterlibatan politik aparatur birokrasi dalam bentuk dukung mendukung pada proses Pilkada langsung tahun 2010 yang diikuti oleh calon Bupati/Wakil Bupati yang berstatus incumbent, dengan proses Pemilukada langsung serentak tahun 2015 yang tidak diikuti oleh incumbent di Kabupaten Pandeglang.

Data penelitian diperoleh melalui observasi, wawancara (interview) mendalam, dan studi pustaka. Observasi dilakukan dengan melakukan pengamatan langsung di lapangan seperti pada saat acara kampanye dan rapat-rapat pemenangan, dan penetapan penghitungan suara hasil Pilkada di KPU Pandeglang. Wawancara dilakukan terhadap informan baik itu sebagai pelaku (tim sukses dari PNS), maupun tim kampanye bukan PNS, dan akademisi dari perguruan

124. Moh Nazir, 2005, Metode Penelitian, Ghalia Indonesia, Bogor, hal 54

125. Dalam Moh Nazir, Ibid, hal 54-55

126. Lexy Moeleong. 2010, Metode Penelitian Kualitatif, Rosda, Bandung, hal 6

127. Lexy Moeleong, ibid, hal 4

$140 \mid$ Cosmogov, Vol. 2 No. 1, April 2016 
tinggi di Kabupaten Pandeglang Banten. Sedangkan studi pustaka dilakukan dengan membaca dan menelaah referensi dari buku-buku, dokumen-dokumen, surat kabar cetak maupun media online.

Setelah data terkumpul kemudian dianalisis dengan menggunakan metode yang dikembangkan oleh Miles dan Huberman yaitu dengan tahapan reduksi data, penyajian data, verifikasi data. ${ }^{128}$ Kemudian data yang sudah dianalisis dilakukan penyimpulan-penyimpulan melalui interpretasi logis.

\section{PEMBAHASAN DAN HASIL}

Pilkada Langsung Pandeglang Tahun 2010, Dukungan Politik Aparatur Birokrasi Terbuka Dengan Intensitas Tinggi

Pemilihan Kepala Daerah (Pilkada) Langsung Kabupaten Pandeglang yang dilaksankan tahun 2010 diikuti oleh enam pasang calon yaitu :

\section{Pertama; Pasangan Yoyon} Sudjana dan Muhamad Oyim dari jalur perseorangan/independen

Kedua; Pasangan Sunarto dan Agus Wahyu Werdana dari jalur perseorangan/independen
Ketiga; Pasangan Djajat Mujahidin dan Enjat Sudrajat dari jalur perseorangan/independen

Keempat; Pasangan Edi Suhaedi dan Aprilia Hedysanty dari Partai Amanat Nasional (PAN) Partai Bulan Bintang, Partai Gerindra, Partai Bintang Reformasi, Partai Merdeka, Partai Demokrasi Pembaruan, Partai Republikan, Partai Kebangkitan Nasional Ulama dan Partai Nahdatul Umammah Indonesia

Kelima; Pasangan Irna Narulita dan Apud Mahfud yang didukung oleh Partai Persatuan Pembangunan (PPP) dan Partai Demkrasi Indonesia Perjuangan (PDIP); Partai Pengusaha dan Pekerja Indonesia

Keenam; Pasangan Erwan Kurtubi dan Heriyani dari Partai Golkar, Partai Demokrat, dan Partai Kebangkitan Bangsa (PKB), Partai Keadilan Sejahtera (PKS). Partai Hanura, Partai Karya Peduli Bangsa, PPRN, dan Partai Matahari Bangsa. ${ }^{129}$

Pada Pilkada tahun ini dengan jelas dan terbuka menunjukan adanya keterlibatan politik aparatur birokrasi dalam bentuk dukung-mendukung (berpihak) kepada para kontestan Pilkada langsung yang berlangsung ketat dan diwarnai konflik.

Akan tetapi meskipun diikuti oleh oleh enam pasang calon Bupati/

128. Hamid Patilima, 2009, Metode Penelitian Kualitatif . Alfabeta Bandung, hal 98 129. Arsip Komisi Pemilihan Umum (KPU) Kabupaten Pangelang, 2011 
Wakil Bupati secara umum keberpihakan aparatur birokrasi Kabupaten Pandeglang terkosentrasi/terbagi pada dua pasangan calon yaitu pasangan Irna Narulita-Apud Mahpud, dan pasangan Erwan Kurtubi-Heriyani.

Terbaginya dukungan aparatur birokrasi Kabupaten Pandeglang pada kedua pasangan calon Bupati/Wakl Bupati tersebut dikarenakan calon Bupati Irna Narulita merupakan istri dari Bupati Pandeglang Dimyati Natakusumah yang sudah menjabat Bupati Pandeglang selama dua periode yaitu dari tahun 2000 sampai dengan tahun 2010. Sehingga bagaimanapun juga sosok Dimyati Natakusuma sebagai mantan Bupati Kabupaten Pandeglang masih memiliki berpengaruh di lingkungan aparatur Pemerintah Daerah Kabupaten Pandeglang.

Sedangkan aparatur birokrasi yang mendukung Pasangan Erwan Kurtubi-Heryani karena Erwan Kurtbi merupakan incumbent. Selain itu juga pasangan ini didukung oleh Ratu Atut Chosiyah (Gubernur Banten) yang merupakan anak tiri dari Heriyani. Dengan demikian pasangan calon Bupati/Wakil Bupati Kabupaten Pandeglang Erwan Kurtubi-Heryani selain didukung oleh sebagian aparatur birokrasi Kabupaten Pandeglang juga di dukung oleh aparatur birokrasi Provinsi Banten.

Berdasarkan pengamatan di lapangan aparatur birokrasi (Pegawai Negeri Sipil/PNS) terlihat aparatur birokrasi mengikuti proses sosialisasi, rapat-rapat pemenangan, bahkan pada saat kampanye di tempat-tempat terbuka. ${ }^{130}$

Seperti yang terlihat pada saat rapat strategi pemenangan Irna Narulita-Apud Mahfud di Rumah Makan Rizky. Berdasarkan pengamatan dalam pertemuan rapat ini ada seorang Pegawai Negeri Sipil (PNS) Kabupaten Pandeglang ikut memberikan pengarahan kepada tim sukses non partai yang diikuti oleh kalangan pemuda dari OKP dan relawan calon Bupati/Wakil Bupati Irna NarulitaApud Mahpud. ${ }^{131}$

Menurut Mahyupi (informan yang berstatus PNS) salah seorang tim sukses Irna Narulita membenarkan bahwa di kalangan birokrasi memang terjadi dukung-mendukung terhadap calon kepala daerah Pandeglang tahun 2010. Bahkan ada tim suksesnya.

130. Observasi 5 September 2010, sering terlihat mobil dinas pemerintah daerah Kabupaten Pandeglang dan Provinsi Banten mengikuti iring-iringan kampanye pasangan calon Bupati/ Wakil Bupati Erwan Kurtubi Heryani.

131. Observasi , 23 September 2010

142 Cosmogov, Vol. 2 No. 1, April 2016 
"Tim sukses dibentuk tetapi tidak secara formal dan tidak ada data tertulis resmi. Tetapi meskipun demikian kita tahu siapa yang mendukung Irna dan siapa yang mendukung Erwan. Bahkan agar tim menajdi solid kita pun melakukan komunkasi dan koordinasi secara intens melakukan pertemuan-petemuan" $f^{132}$

Lebih lanjut Mahyupi menuturkan sebagai berikut :

Kegiatan dukungan aparatur birokrasi terhadap calon Bupatil Wakil Bupati terstruktur dan sistematis, mulai dari pejabat eselon dua di tingkatan Sekda, Asda, Kepala Dinas, CamatCamat, Golongan fungsional seperti guru, sampai dengan kepala desa RT dan RW. Kita mendekati mereka yang kira-kira sepaham dengan pemikiran kita mendukung pasangan Irna-Apud. Karena kita pun menyadari bahwa sebagian aparatur birokrasi Pemda Pandeglang juga mendukung pasangan Erwan dan Heriyani, mereka juga melakukan hal yang sama dengan kita. Bahkan mereka yang mendukung Erwan lebih diuntungan karena Erwan Kurtubi stausnya Bupati sekarang bisa menggunakan fasilitas dan program Pemda Pandeglang. ${ }^{133}$

Adapun kegiatan yang dilakukan dalam upaya mendukung pasangan calon Bupati/ Wakil Bupati seperti di utarakan Mahyupi sebagai berikut:

1. Dalam rapat-rapat kedinasan pada sesi terakhir, selalu disoialisasikan dan diingatkan bahwa ada calon Bupati/Wakil Bupati yang harus dibantu dan diperjungkan meskipun dalam bahasa yang tidak lugas

2. Dalam rapat-rapat diluar dinas, seperti di hotel di Carita kita mengundang tokoh masyarakat setempat supaya mendukung pasangan Irna Narulita-Apud Mahpud

3. Pada kedgiatan sosial seperti pembagian sembako, kita katakana bahwa bantuan itu berasal dari calon yang didukung oleh kita

4. Pada acara-acara keagamaan masyarakat, seperti Maulid Nabi di Masjid kita pun turut mengkondisikan dan hadir, serta

132. Wawancara Mahyupi, 20 November 2015

133. Wawancara Mahyupi, 20 November 2015 
memberikan bantuan untuk kegiatan tersebut

5. Pada saat seminggu menjelang pencoblosan kita ikut keliling ke setiap daerah pemilihan mengecek dan konsolidasi untuk memastikan apakah suara kita diwilayah daerah pemilihan/TPS tertentu aman atau tidak.

6. Melakukan komunikasi dan koordinasi dan evaluasi baik dengan sesama PNS lain maupun dengan masyarakat dalam rangka menyukseskan yang kita dukung.

7. Melakukan pengawasan, monitoring, dan mencari informasi terhadap kekuatan politik lawan kita terutama pasangan Erwan dan Heriyani. ${ }^{134}$

Ketika ditanya alasan mengapa mereka melakukan dukungan terhadap calon Bupati/Wakil Bupati dalam Pilkada langsung Mahyupi mengutarakan sebagai berikut :

"disamping kita diminta untuk mendukung, kita merasa ingin balas budi kepada pak Dimyati yang waktu itu Bupati Pandeglang karena pada saat dia menjabat Bupati telah banyak memperhatikan kita, kita diberikan kepercayaan untuk menduduki jabatan/memimpin di Pemerintah
Daerah Pandeglang. Jika Irna (istri Dimyati) menang pasti kita akan dipercaya kembali menduduki jabatan tersebut bahkan jabatan kita bisa naik lagi. Tetapi jika yang menang bukan Irna, kita terancam tidak akan diberikan kepercayaan bahkan kita akan diturunkan jabatan. ${ }^{135}$

Pada akhirnya setelah pencoblosan Pilkada langsung dilaksankan 3 Oktober 2010 hasil perolehan suara menunjukan bahwa pasangan Erwan Kurtubi-Heryani unggul tipis dalam perolehan suara pada pencoblosan awal yang digelar 3 Oktober 2010 dengan mengumpulkan 239.510 suara atau 43 persen dari total suara sah 552.894. Sedangankan pasangan Irna Narulita-Apud Mahpud yang menjadi saingan terberatnya memperoleh 204.652 suara atau 37 persen. ${ }^{136}$

Berdasarkan data tersebut, maka pemenang Pemilukada langsung di Kabupaten Pandeglang yang diselenggrakan 3 Oktober 2010 adalah pasangan Erwan Kurtubi-Heryani yang merupakan incumbent.

Akan tetapi kemenangan Erwan Kurtubi-Heryani tersebut digugat ke Mahkamah Konstitusi (MK) oleh

134. Wawancara Mahyupi, 2 Desember 2015

135. Wawancara Mahyupi, 2 November 2015

136. Arsip Komisi Pemilihan Umum (KPU) Kabupaten Pandeglang, 2011

144 Cosmogov, Vol. 2 No. 1, April 2016 
pasangan calon Bupati/Wakil Bupati Irna Narulita-Apud Mahpud karena dianggap curang. Salah satu kecurangan pasangan Erwan KurtubiHeryani yang dilaporkan Pasangan Irna Narulita-Apud Mahpud karena melibatkan aparatur birokrasi.

Erwan Kurtubi yang masih menjabat sebagai Bupati Pandeglang terbukti telah mengeluarkan Surat Edaran No. 6 Tahun 2010 tertanggal 21 September 2010, yang isinya menekankan/menyuruh seluruh pegawai pada tiap Satuan Kerja Perangkat Daerah (SKPD) mencoblos pasangan nomor 6 pada Pilkada langsung 3 Oktober 2010. ${ }^{137}$

Bukti Surat edaran itu disampaikan ke Mahkamah Konstitusi (MK) dan didukung oleh kesaksian tujuh belas Pegawai Negeri Sipil (PNS) Kabupaten Pandeglang. Tujuh belas Pegawai Negeri Sipil (PNS) tersebut merupakan para pendukung pasangan calon Bupati/Wakil Bupati Irna Narulita-Apud Mahpud sebagai lawan utama dari pasangan Erwan KutubiHeryani.

Meskipun sebelumnya Erwan Kurtubi membantah adanya surat edaran tersebut, tetapi karena adanya kesaksian tujuh belas PNS tersebut telah menguatkan bukti bahwa telah terjadi kecurangan di Pilkada langsung Pandeglang 3 Oktober 2010 yaitu mobilisasi PNS Kabupaten Pandeglang secara terstruktur, sistematis dan masif.

Akhirnya Mahkamah Konstitusi (MK) memenangkan gugatan kubu Irna Narulita-Apud Mahpud pada tanggal 4 November 2010 melalui Putusan Nomor 190/ PHPU.D-VII/2010 yang membatalkan Keputusan KPUD Pandeglang Nomor 29/KPU-PDG/X/Tahun 2010 Tentang Penetapan Rekapitulasi Hasil Dan Penghitungan Suara. ${ }^{138}$

Ini artinya hasil Pemilukada Pandeglang yang dilaksanakan 3 Oktober 2010 dianggap tidak sah. Kemudian MK mengintruksikan agar dilakukan Pemilukada ulang yang harus dilaksankan 26 Desember 2010 di seluruh Tempat Pemungutan Suara (TPS) di Kabupaten Pandeglang. Dalam Putusan atas gugatan hasil Pilkada yang diajukan pasangan Irna Narulita-Apud Mahpud itu Mahkamah Konstitusi juga menyatakan pencoblosan ulang diikuti semua pasangan

137. www.antaranews.com, edisi kamis 4 November 2010, "MK Kabulkan Gugatan, Perintahkan Pilkada Pandeglang Diulang"

138. www.antaranews.com, edisi kamis 4 November 2010, "MK Kabulkan Gugatan, Perintahkan Pilkada Pandeglang Diulang" 
calon yang ikut dalam Pemilukada langsung di Kabupaten Pandeglang. ${ }^{139}$

Menindaklajuti intruksi Mahkamah Konstitusi (MK) mengenai Pilkada Pandeglang yang harus diulang pada tanggal 26 Desember 2010, seluruh peserta Pemilukada akhirnya mengikuti intruksi tersebut. Seperti mengikuti proses kampanye meskipun dengan sumberdaya yang tesisa.

Pada Pemilukada ulang ini dukungan birokrasi masih terbagi dua yaitu kepada pasangan Irna NarulitaApud Mahpud dan pasangan ErwanHeryani. Pada Pilkada ulang ini persaingan kedua pasangan calon Bupati/Wakil Bupati yang melibatkan dua kubu birokrasi semakin ketat. Bagi aparatur birokrasi karena sudah kepalang basah terlibat mendukung pasangan Bupati/Wakil Bupati, pada Pemilukada ulang ini mereka terlihat benar-benar serius dan lebih bekerja keras lagi dalam memperjuangakan dan memenangkan dukungannya, karena mereka menyadari bahwa yang dipertaruhkan adalah karir dan jabatan mereka.

Setelah mengikuti proses kampanye dan dilakukan Pilkada ulang tanggal 26 Desember 2015 hasilnya menunjukan bahwa pemenang masih tetap pada pasangan Erwan KurtubiHeryani sebagai incumbent.

Adapun hasil penghitungan suara yang dilakukan oleh KPU Kabupaten Pandeglang berdasarkann urutan suara terbanyak adalah sebagai berikut :

1 Pasangan Erwan Kutubi-Heryani memperoleh 265.263 suara atau 49,62 persen

2. Pasangan IrnaNarulita-Apud Mahpud memperoleh 220.624 suara atau 41, 27 persen

3. Pasangan Yoyon SudjanaMuhamad Oyim memperoleh suara 22.003 Suara atau 4,12 persen

4. Pasangan Edi Suhaedi-Aprilia Hedysanty Puteri mempreoleh suara 13.707 suara atau 2,56 persen

5. Pasangan Sunarto-Agus Wahyu Wardana 6.471 suara atau 1,21 persen

6. Pasangan Djajat MudjahidinEnjat Sudrajat memperoleh suara 6.426 suara atau 1,20 persen. ${ }^{140}$

Melihat kenyataan itu kembali pasangan calon Bupati/Wakil Bupati Pandeglang Irna Narulita-Apud Mahfud mengajukan gugatan ke

139. www.antaranews.com, edisi kamis 4 November 2010, “MK Kabulkan Gugatan, Perintahkan Pilkada Pandeglang Diulang"

140. Arsip Komisi Pemilihan Umum (KPU) Kabupaten Pandeglang, 2011

146 Cosmogov, Vol. 2 No. 1, April 2016 
Mahkamah Konstutusi (MK) karena Pilkada lansung ulang juga dianggap penuh dengan kecurangan yang dilakukan oleh pasangan Erwan Kurtubi-Heryani.

Akan tetapi Mahkamah Konstitusi (MK) menolak gugatan hasil pencoblosan yang diajukan pasangan Irna Narulita-Apud Mahfud, dan menetapkan Erwan Kurtubi-Heryani sebagai pemenang Pilkada langsung Kabupaten Pandeglang. Dalam persidangan di Mahkamah Konstitusi (MK) tanggal 31 Januari 2011 Mahkamah Konstitusi yang diketuai Mahfud MD menetapkan pasangan nomor 6 Erwan Kurtubi-Heryani sebagai pemenang Pilkada Pandeglang. ${ }^{141}$

Setelah pasangan Erwan KurtubiHeryani resmi dilatik menjadi Bupati dan Wakil Bupati, tidak lama setelah itu terjadi perombakan besar-besaran di dalam struktur organisasi Pemerintahan (birokrasi) Kabupaten Pandeglang. Semua aparatur birokrasi yang pada Pilkada langsung mendukung pasangan Irna Narulita-Apud Mahpud diberhentikan dari jabatannya, termasuk tujuh belas PNS yang bersaksi di Mahkamah Konstitusi. Mereka tidak diberikan jabatan bahkan didemosi dari jabatnnya.
Kemudian sebagai penggantinya diisi oleh apartaur birokrasi yang mendukung Erwan Kurtubi-Heryani. Pengangkatan ini dilakukan sebagai komitmen dan balas jasa kepada aparatur birokrasi yang berjuang mendukung pasangan Erwan KurtubiHeryani. Seperti yang diutarakan oleh Mahyupi :

"Setelah Erwan Kurtubi dinyatakan menang oleh Mahkamah Konstitusi, kemudian resmi dilatik menjadi Bupati Pandeglang, akhirnya kami pun yang mendukung pasangan calon Bupati/ Wakil Bupati Irna Narulita-Apud Mahpud dicopot dari jabatan pemerintahan. Saya sendiri yang tadinya menjabat Sekretaris Dinas Pertanian dan Peternakan dijadikan guru SD di Kecamatan Labuan. Begitu pula dengan teman-teman yang lain semuanya dicopot dari jabatannya dan digantikan oleh orang-orang yang mendukung Erwan KurtubiHeryani. " 142

\section{Pemilukada Langsung Serentak Pandeglang Tahun 2015, Dukungan Politik Birokrasi Tertutup Dengan Intensitas Rendah}

Pemilu Kepala Daerah Langsung Serentak tahun 2015 di Kabupaten

141. www.antaranews.com, edisi Senin 31 Januari 2011 "MK Tetapkan Erwan-Heryani Pemenang Pilkada Pandeglang"

142. Wawancara Mahyupi, 6 November 2015 
Pandeglang diikuti oleh tiga pasangan calon Bupati/Wakil Bupati yaitu : Nomor urutan satu Aap Aptadi dan Dodo Juanda merupakan calon yang berasal dari jalur independen, Nomor Urut dua yaitu Irna Narulita dan Tanto Warsono Arban, didukung oleh Partai Golkar, Partai Nasdem, Partai Hanura, Partai Kebangkitan Bangsa (PKB) Partai Bulan Bintang, Partai Hanura, Partai Gerindra dan Nomor urut tiga Ratu Siti Romlah dan Yan Riadi, didukung oleh Partai Demokrat, Partai Demokrasi Indonesia Perjuangan (PDIP), Partai PersatuanPembangunan (PPP). ${ }^{143}$

Calon nomor urut satu Aap Aptadi merupakan tokoh Lembaga Sosial Kemasyarakatan (LSM) yang berpengaruh di Kabupaten Pandeglang dan Dodo Juanda merupakan mantan birokrat, jabatan terahirnya Sekretaris Daerah (Sekda) Kabupaten Pandeglang sampai tahun 2014.

Calon nomor urut dua Irna Narulita seorang politisi Partai Persatuan Pembangunan (PPP) yang menjabat anggota DPR RI periode 2014-2019. Irna juga merupakan istri Bupati Pandeglang periode 2001-2011 Dimyati Natakusuma yang pada Pemilukada langsung tahun 2010 ikut mencalonkan diri menjadi Bupati Pandeglang tetapi kalah oleh pasangan calon Bupati Pandeglang Erwan Kurtubi. Sedangkan Tanto Warsono Arban adalah anggota DPRD Provinsi Banten dan Ketua Umum DPD KNPI Provinsi Banten yang juga menantu RatuAtut Chosiyah (mantan Gubernur Banten).

Calon nomor urut tiga Siti Romlah Pernah menjadi anggota Dewan Perwakilan Rakyat (DPR) dari Partai Demokrat. Dan Wakilnya Yan Riyadi adalah perwakilan dari Partai Demokrasi Indonesia Perjuangan (PDIP).

Pada Pemilukada langsung serentak tahun 2015 yang menarik adalah tidak ikutnya Bupati Pandeglang Erwan Kurtubi dan Wakil Heryani menjadi kontestan/calon Bupati/Wakil Bupati Pandeglang. Dengan demikian maka Pemilukada langsung serentak tahun 2015 di Kabupaten Pandeglang tidak diikuti oleh incumbent. Keadaan ini berbeda dengan daerah Kabupaten/Kota yang lain di Provinsi Banten yang semuanya Pemilukada langsung serentak diikuti oleh incumbent yaitu Kota Cilegon, Kota Tangerang Selatan, Kabupaten Serang.

143. Surat Keputusan (KPU) Pandeglang No 46.Kpts/kpu-kab/PDG-015.336409/VIII/2015 Tentang Penetapan Pasangan Calon Bupati dan Wakil Bupati Pada Pemilihan Bupati dan Wakil Bupati Kabupaten Pandeglang 2015 
Berbeda dengan tahun 2010 pada Pilkada serentak 2015 situasi sosial politik di Kabupaten Pandeglang terlihat relatif tidak begitu menunjukan suasana "panas". Tidak terasa adanya persaingan yang ketat diantara pasangan calon Bupati/Wakil Bupati.

Dalam pantauan di lapangan pada saat masa kampanye terbuka tidak terlihat adanya pihak apartaur birokrasi mengikuti kampanye-kampanye yang dilakukan oleh calon Bupati/Wakil Bupati. ${ }^{144}$ Kampanye berjalan tertib tidak ada suasana persaingan/konflik diantara pendukung ketiga calon pasangan Bupati dan Wakil Bupati, semua berjalan seperti biasa sesuai dengan prosedur yang telah ditetapkan KPU Kabupaten Pandeglang.

Pada Pemilukada serentak 2015 tampaknya aparatur birokrasi Kabupaten Pandeglang sepertinya tidak melakukan kegiatan dukung mendukung terhadap calon Bupati/Wakil Bupati. Seperti dalam internal organisasi birokrasi tidak adanya intruksi-intruksi dari pimpinan Satuan Kerja Perangkat Daerah (SKPD) agar mendukung calon Bupati tertentu.
Dalam rapat-rapat maupun kampanye terbatas di desa-desa pemenangan calon Bupati/Wakil Bupati tidak terlihat adanya aparatur birokrasi yang terlibat/ikut dalam acara tersebut. ${ }^{145}$

Menurut Epi Sutiasa, Camat Kecamat an Sumur menyatakan bahwa sekarang tidak ada lagi intruksiintruksi untuk memenangkan calon Bupati/Wakil Bupati. Karena dalam aturan jangankan sengaja ikut, kita lewat tidak sengaja saja ke lokasi pertemuan/kampanye bisa dilaporkan oleh Panwaslu atau masyarakat. ${ }^{146}$

Pernyataan yang sama juga dikemukakan oleh Camat Sukaresmi, Baasyar, menurut Baasyar :

"sekarang tidak ada lagi dukung mendukung terhadap calon Bupati/WakilBupati. Di lingkunan kerja saya PNS dipersilahkan bebas untuk memilih sesuai dengan penilaiannya siapa yang layak untuk menjadi Bupati/Wakil Bupati karena di dalam aturannya sudah jelas birokrasi harus netral" "147

Tidak adanya intruksi/perintah dari pimpinan organisasi pemerintah

144. Observasi 7 November 2015 Tidak tampak lagi iringpiringan kampanye calon Bupati/Wakil Bupati Kabupaten Pandeglang diikuti oleh PNS yang menggunakan mobil dinas Pemda atau fasilitas lainnya.

145. Observasi Kampanye di Kecamatan Saketi, 25 November 2015

146. Wawancara Epi Sutiasa(Camat Sumur), 15 November 2015

147. Wawancara Baasyar (Camat Sukaresmi), 17 November 2015 
daerah Kabupaten Padeglang juga diperkuat oleh pernyataan Hasan Slamet, Staf PNS Kecamatan Saketi yang mengemukaakan bahwa menurut sepengetahuannya dalam Pemilukada langsung serentak tahun 2015 tidak ada intruksi-intruksi/arahan dari atasan (Camat) supaya memilih calon tertentu pada Pilkada langsung serentak 2015 di Kabupaten Pandeglang. ${ }^{148}$

Akan tetapi menurut Asep Muslim, seorang PNS Dinas Pendapatan Daerah (Dispenda) Kabupaten Pandeglang seperti yang diungkapkannya :

"saya merasakan adanya suasana dukung mendukung terhadap calon Bupati/Wakil Bupati Pandeglang meskipun tidak ada kata-kata/instuksi lansung. Sepertinya di tempat saya berkerja ketiga calon tersebut ada pendukungnya. Suasana kerja sudah kurang fokus, mungkin akan ada perombakan/ mutasi pegawai dalam waktu dekat ini". ${ }^{149}$

Adanya indikasi keterlibatan politik aparatur birokrasi pada Pemilukada serentak dikemukakan oleh Nasrullah (Tim sukses Irna
Narulita-Tanto Warsono Arban). Menurut Nasrullah :

"biokrasi Pandeglang ada
sebagian yang mendukung
pasangan calon Bupati/Wakil Bupati Aap Aptadi-Dodo Juanda. Karena adanya faktor Dodo Juanda yang mantan Sekda Pandeglang. Dipilihnya Dodo Juanda menjadi calon Wakil Bupati oleh Aap Aptadi karena diharapkan dapat mempengaruhi aparatur birokrasi kepada pasangan mereka. Bagaimanapun juga banyak aparatur birokrasi yang jadi pejabat saat ini karena diusulkan/diangkat oleh Dodo Juanda yang menjabat Sekda sampai 2014"'150

Masih adanya aparatur birokrasi yang melakukan dukungan terhadap calon Bupati/Wakil Bupati dalam Pemilukada serentak dinyatakan pula oleh Ade Sudirman (Dosen Universitas Mathla'ul Anwar Fakultas Ilmu Sosial dan Ilmu Politik):

"Dukung mendukung secara politik terhadap calon Bupati/ Wakil Bupati pasti tetap ada, karena bagaimanapun juga calon bupati yang terpilih nanti memiliki hak/kebijakan untuk memilih dan mengangkat

148. Wawancara Hasan Slamet (Staf PNS Kecamatan Saketi), 20 November 2015

149. Wawancara Asep Muslim (PNS Dispenda) Kabupaten Pandeglang 21 November 2015

150. Wawancara Nasrullah (Tim Sukses pasangan calon Bupati/Wakil Bupati Irna Narulita-Tanto

W Arban) 25 November 2015

150 Cosmogov, Vol. 2 No. 1, April 2016 
aparatur pegawai negeri sipil menjadi pejabat-pjabat daerah seperti Camat, Kepala Dinas, Asda, Sekda dan lain-lain. Akan tetapi tentunya untuk sekarang tidak bisa lagi aparatur birokrasi mendukung secara terbuka seperti masa lalu. Karena sekarang regulasinya semakin ketat seperti adanya UU ASN, dan Surat Edaran dari Menpan yang melarang dan mengancam aparaur birokrasi yang terbukti terlibat dukung mendukung dapat langsung dipecat. Selain itu juga masyarakat sekarang sudah semakin pintar, kritis dan berani melaporkan oknum PNS yang coba-coba mendukung calon tertentu. Dan yang paling berpengaruh mengapa birokrasi saat ini tidak bisa secara terbuka mendukung calon Bupati/Wakil Bupati tertentu karena Erwan Kurtubi Bupati Pandeglang selaku incumbent tidak mencalonkan lagi mejadi Bupati tahun ini. Sehingga pejabat-pejabat birokrasi saat ini bingung memilih/ mendukung siapa”?. ${ }^{151}$

Ketika ditanya mengapa apartur birokrasi terlibat dalam dukung mendukung calon Bupati/Wakil Bupati meskipu melanggar aturan Ade Sudirman menuturkan "dari dulu juga aturan undangundang maupun peraturan pemerintah memang ada, tapi kenyataanya di lapangan sebenarnya banyak pelanggaran dalam pemilukada oleh apartur birokrasi. Tetapi belum pernah ada saya menemukan apartur birokrasi yang melaggaran aturan itu diberikan sanksi misalnya diberhentikan. Jangankan diberhentikan diproses juga tidak seprti 17 PNS yang bersaksi di MK. Ini terjadi karena lembaga yang berweweng seperti Panwaslu bersifat pasif, mereka hanya menerima laporan, dan melanjutkan laporan tersebut. ${ }^{152}$

Ketika ditanya aparatur birokrasi pada Pemilukada langsung serentak akan memilih siapa?, Ade Sudirman mengungkapkan pendapatnya ;

"Menurut saya birokrasi saat ini akan memilih/mendukung calon Bupati/Wakil Bupati yang memiliki peluang besar untuk terpilih menjadi Bupati/Wakil Bupati. Jadi karena tidak diikuti oleh incumbent dukungan politik birokrasi tertuju kepada calon yang kira-kira memiliki dukungan

151. Wawancara Ade Sudirman, 29 November 2015

152. Wawancara Ade Sudirman, 29 November 2015 
besar dari masyarakat. Saat ini calon yang berpeluang menjadi Bupati adalah Irna Narulita. Karena Irna sudah dikenal oleh masyarakat dibandingkan calon yang lainnya. Meskipun kalah pada tahun 2010, dia menjadi anggota DPR yang rajin berkujung ke Pandeglang. ${ }^{153}$

Pernyataan Ade Sudirman tersebut diperkuat oleh Mahyupi, Menurut Mahyupi dukungan PNS terhadap pasangan Irna Narulita ada, terutama dari sebagian parapendukung tahun 2010 ketika Irna kalah, mereka masih loyal, saat inipun mereka masih mendukung. Dukungannya hanya sebatas komunikasi, karena kita sekarang memiliki ruang gerak yang terbatas, tidak bisa lagi turun ke lapangan ikut kampanye seperti tahun-tahun yang lalu. Lebih lanjut Mahyupi menuturkan :

"bahkan para pejabat birokrasi Kabupaten Pandeglang yang pada Pemilukada 2010 menjadi lawan kita sekarang merapat/ mengunjungi Dimyati Natakusumah di Jakarta yang kemungkinan menyatakan dukungan/ komitmen mendukung Irna Narulita. Karena Irna dianggap memiliku suara paling kuat dalam memenangkan Pemilukada serentak tahun ini"'154.

Setelah dilakukan pencoblosan pada 9 Desember 2015 ternyata hasilnya menujukan bahwa pasangan Irna Narulita-Tanto Warsono Arban memenangkan Pemilukada Serentak dengan perolehan suara yang jauh dari kedua pasangan calon Bupati yang menjadi saingannya. Irna Narulita memperoleh suara 367.547 atau 69 persen total suara. Secara rinci hasil perhitungan perolehan suara Pemilukada langsung serentak dari KPUD Kabupaten Pandeglang sebagai berikut:

Pasangan calon Bupati dan Wakil Bupati nomor urut 1 Aap Aptadi dan Dodo Juanda meperoleh suara 103.296 (Seratus tiga ribu duaratus sembilan puluh enam ribu) suara. Pasangan calon Bupati dan Wakil Bupati nomor urut 2 Irna Narulita dan Tanto Warsono Arban meperoleh suara 367.547 (Tiga ratus enampuluh tujuh ribu lima ratus empat puluh tujuh) suara. Pasangan calon Bupati dan Wakil Bupati nomor urut 3 Ratu Siti Romlah dan Yan Riadi memeperoleh suara 58.438(Limapuluh delapan ribu empat ratus tiga puluh delapan) suara. ${ }^{155}$

153. Wawancara Ade Sudirman, 29 November 2015

154. Wawancara Mahyupi, 6 Desember 2015

155. Surat Keputusan Komisi Pemilihan Umum Kabupaten Pandeglang nomor 6/KPU-Kab/PDG015.436409/2015 Tentang Penetapan Rekapitulasi Penghitungan Perolehan Suara Dan Hasil Pemilihan Bupati Dan Wakil Bupati Kabupaten Pandeglang Tahun 2015

152 CosmoGov, Vol. 2 No. 1, April 2016 
Dengan demikian pada Pemilukada langsung serentak tahun 2015 di Kabupaten Pandeglang yang tidak diikuti oleh incumbent dimenangkan oleh Pasangan Irna Narulita-Tanto Warsono Arban.

Kemudian setelah resmi menjadi Bupati Kabupaten Pandeglang apakah Irna Narulita akan merombak/mengganti orang-orang Erwan Kurtubi yang menduduki jabatan-jabatan dalam struktur birokrasi (Satua Kerja Perangkat Daerah) Kabupaten Pandeglang?. Menurut Nasrullah sudah ada sebagian orang-orang yang direncanakan untuk menduduki jabatanjabatan tertentu di srtuktur pemerintahan Kabupaten Pandeglang, orang-orang tersebut adalah aparatur birokrasi yang dulu tahun 2010 berjuang/mendukung Irna Narulita menjadi Calon Bupati Kabupaten Pandeglang. ${ }^{156}$

\section{Analisis Motif Keterlibatan \\ Birokrasi Pada Pemilukada \\ Langsung di Kabupaten \\ Pandeglang}

Sebenarnya sejak reformasi bergulir, aparatur birokrasi (PNS) tidak diperbolehkan terlibat dalam kegiatan politik praktis seperti menjadi anggota partai politik, dukung mendukung dalam Pemilu DPR, DPD, Presiden/Wakil Presiden, maupun Pemilu Kepala Daerah. Larangan ini tertuang dalam Peraturan Undang-Undang yang secara legal formal mengikat dan harus dipatuhi oleh aparatur birokrasi.

Setidaknya sudah ada enam aturan perundang-undangan di era reformasi yang menyatakan bahwa PNS tidak diperbolehkan melakukan kegiatan politik termasuk dukungmendukung terhadap calon Bupati/ Wakil Pupati yaitu:

Pertama Undang-Undang Nomor 43 Tahun 1999 Tentang Perubahan Atas Undang-Undang Nomor 8 Tahun 1974 Tentang Pokok-Pokok Kepegawaian, yang berbunyi: "Dalam kedudukan dan tugas sebagaimana dimaksud dalam ayat (1), Pegawai negeri harus netral dari pengaruh semua golongan dan partai politik serta tidak diskriminasif dalam memberikan pelayanan kepada masyarakat" ${ }^{\prime 57}$

Kedua Undang-Undang Nomor 10 Tahun 2008 Tentang Pemilihan Umum, yang berbunyi "Pemerintah, pemerintah provinsi, pemerintah kabupaten/kota, kecamatan desa/ kelurahan, tentara Nasional Indonesia

156. Wawancara Nasrullah, 15 Desember 2015

157. Undang-Undang Nomor 43 Tahun 1999 Tentang Perubahan Atas Undang-Undang Nomor 8 Tahun 1974 Tentang Pokok-Pokok Kepegawaian pasal 3 ayat 1 
dan Kepolisian Negara Republik Indonesia dilarang melakukan tindakan yang menguntungkan atau merugikan salah satu pelaksana kampanye"'158

Ketiga Undang-Undang Nomor 32 Tahun 2004 Tentang Pemerintah Daerah, yang berbunyi "Pasangan Calon dilarang melibatkan pegawai negeri sipil, anggota Tentara nasional Indonesia, dan anggota Kepolisisan Negara Republik Indonesia sebagai peserta kampanye dan juru kampanye dalam pemilihan kepala daerah dan wakil kepala daerah"159

\section{Keempat Undang-Undang} Nomor 5 Tahun 2014 Tentang Aparatur Sipil Negara, yang berbunyi "Penyelenggaraan kebijakan dan Manajemen ASN berdasarkan pasa asas netralitas yang maksudnya pada Huruff Yang dimaksud dengan "asas netralitas" adalah bahwa setiap Pegawai ASN tidak berpihak dari segala bentuk pengaruh manapun dan tidak memihak kepada kepentingan siapapun"160

Kelima, Undang-Undang Republik Indonesia Nomor 1 Tahun 2015
Tentang Penetapan Peraturan Pemerintah Pengganti Undang-Undang Nomor 1 Tahun 2014 Tentang Pemilihan Gubernur, Bupati, Dan Walikota Menjadi Undang-Undang yang berbunyi:

"Dalam Kampanye calon dilarang melibatkan Apartur Sipil Negara, Angggota Kepolisian Republik Indonesia, dan Anggota Tentara Nasional Republik Indonesia"

"Pejabat Negara, pejabat aparatur Sipiol Negara, dan Kepala Desa/Lurah dilarang membuat keputusan dan/tindakan yang menguntungkan atau merugikan salah satu calon selama masa Kampanye"161

Keenam, Peraturan Pemerintah Nomor 37 Tahun 2004 Tentang Larangan Pegawai Negeri Sipil menjadi Anggota Partai Politik, yang berbunyi "Pegawai Negeri Sipil dilarang menjadi anggota dan/atau pengurus partai politik ayat (2). Pegawai Negeri Sipil yang menjadi anggota dan/atau pengurus partai politik diberhentikan sebagai Pegawai Negeri Sipil"162

158. Undang-Undang Nomor 10 Tahun 2008 Tentang Pemilihan Umum pasal 102 ayat 2 159. Undang-Undang Nomor 32 Tahun 2004 Tentang Pemerintah Daerah pasal 79 Ayat 4 160. Undang-Undang Nomor 5 Tahun 2014 Tentang Aparatur Sipil Negara Pasal 2

161. Undang-Undang Republik Indonesia Nomor 1 Tahun 2015 Tentang Penetapan Peraturan Pemerintah Pengganti Undang-Undang Nomor 1 Tahun 2014 Tentang Pemilihan Gubernur, Bupati, Dan Walikota Menjadi Undang-Undang, Pasal 70 dan 71

162. Peraturan Pemerintah Nomor 37 Tahun 2004 Tentang Larangan Pegawai Negeri Sipil Menjadi Anggota Partai Politik Pasal 2 ayat 1 
Ketujuh, Peraturan Pemerintah Nomor 53 Tahun 2010 Tentang Disiplin Pegawai Negeri Sipil Pasal 3 ayat 15 : Pegawai Negri Sipil dilarang memberikan dukungan kepada calon Kepala Daerah/Wakil Kepala Daerah, dengan cara: a. terlibat dalam kegiatan kampanye untuk mendukung calon Kepala Daerah/Wakil Kepala Daerah; b. menggunakan fasilitas yang terkait dengan jabatan dalam kegiatan kampanye; c. membuat keputusan dan/atau tindakan yang menguntungkan atau merugikan salah satu pasangan calon selama masa kampanye; dan/atau d. mengadakan kegiatan yang mengarah kepada keberpihakan terhadap pasangan calon yang menjadi peserta pemilu sebelum, selama, dan sesudah masa kampanye meliputi pertemuan, ajakan, himbauan, seruan, atau pemberian barang kepada PNS dalam lingkungan unit kerjanya, anggota keluarga, dan masyarakat."163

Ketujuh aturan perundangundangan tersebut cukup jelas dan tegas melarang PNS terlibat pada kegiatan politik dalam bentuk apapun, termasuk dukung mendukung terhadap salah satu calon Kepala Daerah dan Wakil Kepala Daerah dalam Pilkada langsung.
Tetapi tampaknya aturan/kebijakan tersebut tidak lantas membuat aparatur birokrasi (PNS) patuh. Pada kenyataanya mereka lebih tergoda mendapatkan jabatan dalam struktur birokrasi dengan terlibat dalam kegiatan politik praktis dalam bentuk dukung-mendukung terhadap calon Bupati/Wakil Bupati. Apalagi jika Pilkada lansung pesertanya incumbent, dan penguasa/incumbent tersebut melakukan perintah/tekanan agar mereka mendukung.

Seperti yang terjadi di Kabupaten Pandeglang, pada Pilkada langsung tahun 2010 yang diikuti incumbent menunjukan adanya keterlibatan politik aparatur birokrasi dalam bentuk dukung-mendukung terhadap calon Bupati/Wakil Bupati.

Dengan adanya Surat Edaran No. 6 Tahun 2010 tertanggal 21 September 2010, dari Bupati Kabupaten Pandeglang yang isinya menekankan/menyuruh seluruh pegawai pada tiap Satuan Kerja Perangkat Daerah (SKPD) mencoblos pasangan nomor 6 pada Pilkada langsung 3 Oktober 2010 yang dijadikan alat bukti terjadinya kecuarangan di Mahkamah Konstutusi (MK) dan adanya saksi dari pihak Pegawai Negeri Sipil (PNS) Kabu-

163. Peraturan Pemerintah Nomor 53 Tahun 2010 Tentang Disiplin Pegawai Negeri Sipil Pasal 3 ayat 15 
paten Pandeglang menunjukan keterlibatan birokrasi dalam mendukung calon Wakil Bupati/Wakil Bupati terjadi secara terbuka dengan intensitas tinggi.

Sedangkan pada Pemilukada serentak tahun 2015 yang tidak diikuti oleh incumbent berdasarkan pemantauan di lapangan (observasi) dan interview, menunjukan bahwa keterlibatan apratur birokrasi dalam dukung mendukung Bupati/Wakil Bupati masih tetap ada tetapi tertutup dengan intensitas rendah.

Dengan demikian baik pada Pilkada langsung tahun 2010 yang diikuti oleh incumbent, maupun Pemilukada langsung serentak tahun 2015 yang tidak diikuti oleh incumbent tetap menunjukan adanya keterlibatan politik aparatur birokrasi dalam bentuk dukung mendukung terhadap calon Bupati/Wakil Bupati. Hanya saja pada Pemilukada serentak tahun 2015 dukung mendukung aparatur birokrasi terhadap calon Bupati/Wakil Bupati mengalami penurunan.

Motif atau tujuan utama aparatur birokrasi terlibat politik dengan mendukung calon Bupati/Wakil Bupati karena menginginkan jabatan dan takut kehilangan jabatan. Sehingga akhirnya aparatur birokrasi dengan sukarela atau dengan terpaksa terlibat dalam dukung-mendukung calon Kepala Daerah/Wakil Kepala Daerah pada Pemilukada meskipun itu melanggar aturan.
Dengan demikian aparatur birokrasi tidak sepenuhya dapat netral dalam politik seperti pada saat Pemilukada berlangsung. Keberpihakan kepada calon Bupati/Wakil Bupati masih tetap ada. Hal ini memang dilematis, pada satu sisi, aparat ur birokrasi (PNS) adalah aparat pemerintah yang dituntut untuk bersikap netral dalam melaksanakan tugasnya, sedangkan di sisi lain mereka juga anggota masyarakat yang memiliki kepentingan-kepentingan politis maupun ekonomis tersendiri menyangkut siapa yang akan terpilih. Kenyataanya seringkali terjadi kepentingan-kepentingan tersebut lebih dominan.

Keadaan ini terasa jauh dari konsep ideal birokrasi sebagaimana Max Weber yang menghendaki birokrasi sebagai lembaga yang dijalankan secara rasional, profesional, dan independen. Karena apartur birokrasi bukanlah mesin yang bekerja, tetapi manusia mahluk sosial yang memiliki hasrat dan keinginan, termasuk keinginan untuk memiliki jabatan dan kehormatan serta materi yang berlebih.

Dalam Pemilukada langsung di Kabupaten Pandeglang yang melibatkan aparatur birokrasi juga kurang relavan dengan konsep birokrasi Karl Marx yang menyatakan bahwa birokrasi hanya sebatas alat (instrumen) yang dieksploitasi oleh yang berkuasa/incumbent untuk mendominasi/mempertahankan kekuasaa- 
nya. Karena ternyata dibalik itu ada hubungan timbal balik yang saling menguntungkan (mutualisme) diantara aparatur birokrasi dan calon Bupati/Wakil Bupati.

Dengan adanya dukungan dari birokrasi calon Bupati/Wakil Bupati mendapatkan suara lebih sehingga dapat memenangkan Pemilukada langsung. Karena dengan struktur organisasi yang sudah mapan yang hierarkinya menjangkau tingkat desa, birokrasi merupakan sumber kekuatan politik yang riil, yang mampu mengkooptasi dan memobilisasi masyarakat dalam mendulang perolehan suara secara lebih efektif dan efisien. Sehingga incumbent tidak perlu mengeluarkan ongkos politik yang besar seperti menggerakan partai politik atau pun organisasi masyarakat.

Sedangkan bagi aparatur birokrasi yang mendukung calon Bupati/WakilBupati akan memperoleh balas jasa dalam bentuk pemberian jabatan dalam struktur pemerintahan daerah. Bagi aparatur birokrasi jabatan adalah nilai, sesuatu yang sangat diinginkan dan berharga yang menentukan bertambahnya materi, serta dapat meningkatkan status sosial mereka, baik itu di lingkungan pekerjaan maupun masyarakat.

\section{PENUTUP}

Berdasarkan hasil penelitian dapat disimpulkan, Pilkada langsung yang dilaksanakan tahun 2010 di Kabupaten Pandeglang yang diikuti oleh incumbent menunjukan keterlibatan politik aparatur birokrasi dalam bentuk dukung mendukung terhadap calon Bupati/Wakil Bupati tampak terbuka dengan intensitas yang tinggi. Sedangkan pada Pemilukada langsung serentak tahun 2015 di Pandeglang yang tanpa diikuti incumbent keterlibatan politik aparatur birokrasi dalam bentuk dukung-mendukung terhadap calon Bupati/Wakil Bupati tampak tertutup/ terselubung dengan intensitas rendah.

Dengan demikian keterlibatan politik aparatur birokrasi dalam bentuk dukung mendukung calon Bupati/Wakil Bupati Kabupaten Pandeglang pada Pemilukada serentak tahun 2015 mengalami penurunan, jika dibandingkan dengan Pemilukada langsung tahun 2010. Penurunan ini terjadi salah satu faktor utamanya karena Pemilukada langsung serentak tahun 2015 di Kabupaten Pandeglang tidak diikuti oleh incumbent. Ini artinya keberadaan incumbent sebagai peserta Pemilukada langsung turut berpengaruh dan menjadi penentu tinggi rendahnya tingkat keterlibatan aparatur birokrasi dalam dukung mendukung calon Bupati/Wakil Bupati.

Adapun motif atau tujuan utama aparatur birokrasi terlibat politik dengan mendukung calon Bupati/ Wakil Bupati karena menginginkan jabatan dan takut kehilangan jabatan 
dalam struktur pemerintahan daerah Kabupaten Pandeglang. Sehingga akhirnya aparatur birokrasi dengan sukarela atau terpaksa terlibat dalam dukung-mendukung calon Kepala Daerah/Wakil Kepala Daerah pada Pemilukada meskipun itu melanggar aturan.

Masalahnya jabatan yang diberikan karena sebagai balas jasa politik dengan tidak mempertimbangkan kualifikasi kompetensi cenderung menghasilkan aparatur birokrasi yang kurang profesional dalam menjalankan tugas dan fungsinya. Mereka akan lebih menjadi alat untuk "melayani" kepentingan politik ekonomi penguasa ketimbang melayani masyarakat. Keadaan ini tentunya akan mempengaruhi jalannya pemerintahan dan pembangunan daerah menjadi kurang epektif.

Untuk itulah perlu mendapat perhatian dan dipikirkan bersama bagaimana agar proses politik di daerah (Pemilukada) tidak sampai mengintervensi aparatur birokrasi hingga terjebak pada kegiatan politik praktis di Pemilukada langsung. Adanya berbagai kebijakan melalui peraturan/ undang-undang dan tidak ikut sertanya incumbent ternyata tidak cukup mencegah aparatur birokrasi melakukan kegiatan dukung mendukung kepada Kepala Daerah dalam Pemilukada langsung. Seharusnya Pengawasan yang ketat dan pemberian sanksi yang nyata dan tegas sebagai bentuk penegakan aturan/undang dari peme- rintah harus benar-benar dilaksankan oleh para pihak yang berwenang.

\section{DAFTAR PUSTAKA}

Albrow, Martin, 2004, Birokrasi, Tiara Wacana, Yogyakarta

Ali, M, Markus 2011, Tafsir Kostitusional Pelanggaran Pemilukada yang bersifat Sistematis,

Terstruktur, dan Masif, Pusat Penelitian dan Pengkajian Kepaniteraan dan Sekretarian Jenderal Mahkamah Konstitusi

Departemen Pendidikan dan Kebudayaan; Administrasi Pendidikan Materi Dasar Pendidikan Program Akta mengajar V, Buku II C, Jakarta 1982

Dwiyanto, Agus, 2009, Reformasi Birokrasi Publik di Indonesia, Gadjah Mada University Press.

Moeleong, Lexy. 2010, Metode Penelitian Kualitatif, Rosda, Bandung

Nazir, Moh. 2005. Metode Penelitian. Ghalia Indonesia. Bogor

Patilima, Hamid, 2007, Metode Penelitian Kualitatif, Alfa Beta, Bandung

Surat Keputusan Komisi Pemilihan Umum Kabupaten Pandeglang nomor 6/KPU-Kab/PDG015.436409/2015 Tentang Penetapan Rekapitulasi Penghitungan Perolehan Suara Dan Hasil Pemilihan Bupati Dan Wakil Bupati Kabupaten Pandeglang Tahun 2015. 
Tjokroamidjojo, Bintoro 2001, Reformasi Administrasi Publik, Universitas Krisnadwipayana, Jakarta

Thoha, Miftah. 2009, Birokrasi Pemerintah Indonesia di Era Reformasi, Kencana, Jakarta

Peraturan Pemerintah Nomor 37 Tahun 2004 Tentang Larangan Pegawai Negeri Sipil menjadi Anggota Partai Politik

Peraturan Pemerintah Nomor 53 Tahun 2010 Tentang Disiplin Pegawai Negeri Sipil

Undang-Undang Nomor 43 Tahun 1999 Tentang Perubahan Atas Undang-Undang Nomor 8 Tahun 1974 Tentang Pokok-Pokok Kepegawaian

Undang-Undang Nomor 10 Tahun 2008 Tentang Pemilu Anggota DPR, DPRD, dan DPD
Undang-Undang Nomor 5 Tahun 2014 Tentang Aparatur Sipil Negara

Undang-Undang Nomor 32 Tahun 2003 Tentang Pemerintah Daerah Undang-Undang No 3 Tahun 1975 Tentang Partai Politik dan Golongan Karya

Undang-Undang Republik Indonesia Nomor 1 Tahun 2015 Tentang Penetapan Peraturan Pemerintah Pengganti Undang-Undang Nomor 1 Tahun 2014 Tentang Pemilihan Gubernur, Bupati, Dan Walikota Menjadi UndangUndang

www.antaranews.com, Edisi 4

Oktober 2010 "MK Kabulkan

Gugatan, Perintahkan Pilkada

Pandeglang Diulang

www.antaranews.com/edisi senin 31

Januari 2011. "MK Tetapkan

Erwan-Heryani Pemenang"

Radar Banten, 10 Desember 2015 